\title{
The New Women from the Margins ${ }^{1}$
}

\author{
KATJA MIHURKO PONIŽ \\ VIOLA PARENTE-ČAPKOVÁ
}

\begin{abstract}
The New Woman makes an appearance in the texts of both male and female fin de siècle writers, although unsurprisingly she was more often an important focus for women writers. And although women writers from the margins of Europe faced many challenges that were similar to those of their contemporaries in English speaking countries, they were also simultaneously confronted with local and contextually specific issues. In this article, we tackle the specificities of the literary New Women in Slovenian and Finnish literature, and in particular, the texts of Zofka Kveder (1878-1926) and L. Onerva (1882-1972). Both women writers sought ways of engaging with questions of female identity in societies obsessed with cultural nationalism, and which saw woman primarily in terms of her role as wife and mother. Both L. Onerva and Kveder foregrounded the New Woman, depicting her as wanting to live her life on her own terms, even if this coincided with a painful awareness of the difficulty of such an enterprise. Both writers suggested that the New Woman's personal ambivalences and inhibitions were often felt more acutely than any external force. L. Onerva and Kveder enriched Finnish and Slovenian literature with bold new themes and depictions, adding their own provocative ideas about love, sexuality, and emancipation to those being expressed by other better known New Woman writers, including Ellen Key.
\end{abstract}

Keywords: New Woman, fin de siècle, Slovenian literature, Finnish literature, Zofka Kveder, L. Onerva

The term New Woman originated from within the Anglo-American context, but the depiction of the woman who did not comply with contemporary ideals of womanhood, who looked for alternatives, or who tried to invent a new form of female identity, existed in many literatures. In Europe, some of these new

The research for this article was undertaken in the framework of the CRP "Travelling Texts 1790-1914: The Transnational Reception Of Women's Writing At the Fringes of Europe", financially supported by the HERA Joint Research Programme (www. heranet.info), co-funded by AHRC, AKA, BMBF via PT-DLR, DASTI, ETAG, FCT, FNR, FNRS, FWF, FWO, HAZU, IRC, LMT, MHEST, NWO, NCN, RANNÍS, RCN, VR and The European Community FP7 2007. 
depictions came from the peripheries of the continent. ${ }^{2}$ In this article, we use the term "New Woman" to describe depictions of woman on the cusp of the turn of the nineteenth and the twentieth centuries, ${ }^{3}$ and we concentrate on woman writers from two "Europeripheral" countries, Slovenia and Finland. Our goal is to contribute to the comparative research that is concerned with contexts other than English language ones. ${ }^{4} \mathrm{New}$ Woman writers across Europe and beyond opened heated debates about the place of woman in society, some of which continue to rage even today. Specifically, the issue of the relationship between woman's intellect, creativity, independence, career aspirations and "emancipation" on the one hand, was, and remains at odds with her perceived capacity to love, experience sexual passion and be a mother. Therefore, we believe this article highlights the enduring significance of the texts of these two writers.

The New Woman is to be found in texts by both male and female writers of the fin de siecle, though it is not surprising that she was more commonly the concern of women writers. Although women writers from the margins of Europe faced many challenges that were in some ways similar to those experienced by their contemporaries in English speaking countries, they were, at the same time, confronted with many context specific societal issues. In this article, we intend to address the specificities of the literary New Women ${ }^{5}$ of Finnish and Slovenian literature. Both Finland and Slovenia belonged among

2 We use the term "peripheral" not only in the geographical sense, but also to describe the literature which to a large extent remained on the receiving end of international literary exchanges. Unlike the literatures of countries such as France and England, considered as "exporting" countries, it was imagined that New Woman literatures in the fringes of Europe would need to be "imported" (Moretti 1998; Cohen/Dever 2002).

3 We refer the term New Woman in this very specific way, rather than in the broader sense of the expression, which may also denote depictions of unorthodox femininity from the 1920s and the 1930s, such as the flapper, tomboy, or the other meanings that gained currency during the interwar period.

4 There is already some research in English dealing with the New Woman at the margins of Europe (see e.g. Witt-Brattström 2004), but the majority of research tends to be published in the languages other than English.

5 Fin desiècle women writers' ideas about creativity cannot be separated from their concern with constructing woman's subjectivity, especially when we consider how tightly life and art, and life and writing overlapped within fin de siècle artistic and philosophical currents, and how important the analysis of the self was in those currents - including various forms of Nietzschean inspirations, the Russian doctrine of жизнетворчество, or others (see for example, Pynsent 1994: 101-146; Parente-Čapková 2014: 11). 
the countries undergoing national revival during the period in question, ${ }^{6}$ and both Finnish and Slovenian literatures have been defined in terms of their cultural nationalism as well. ${ }^{7}$ As Joep Leerssen argues, in terms of the development of European nationalism, "the outer corners of the old continent (the Balkans, the Baltic, Ireland) are by no means lagging behind the centre. All these areas were spanned by a Europe-wide circulation of ideas and a Europewide network of intellectuals" (Leerssen 2006: 20). Among nationalisers, there were always women, although their involvement has often been overlooked. Here, we present two women writers from the fringes of Europe who added their own depictions of the New Woman to the European literary tradition. Carol MacKay (1995; see also Launis 2005) uses the term confluence when talking about two women writers, writing in different countries in the same time period and interested in the same topics connected with woman's life. These women writers frequently wrote similar plots and expressed ideas in similar ways. Some New Woman writers were quintessential examples of such confluence, and it is possible to look at the Slovenian writer Zofka Kveder

6 Slovenes did not form an independent state until the late twentieth century. Throughout the long nineteenth century, Slovene lands were part of the Habsburg empire. The majority of Slovenes were Catholic and in the countryside, church authorities endeavoured to draw a particularly strict division between the sexes and tried to contain women within the private sphere. Slovene middle-class women entered public life in 1848, when the national revival culminated. Finland became an independent republic in 1917, after a century of Russian dominion, preceded by six and a half centuries of Swedish rule. The society kept its Nordic character, including the Lutheran religion and comparably favourable conditions for the emancipation of women. A range of important achievements date from the early twentieth cenury, when Finnish women gained the right to vote (1906), and were the first in Europe to do so (1907). They were also granted permission to study at the university without a special permit (1901).

7 The term "cultural nationalism" was invented by Dutch comparative theorist Joep Leerssen. In this transnational discourse, as Marko Juvan argues, for Slovenian literature "the role of language as well as folk traditions, collective memory, literature, culture, art and sciences were the principal - indeed seemingly the only possible - factors that shape and maintain national self-awareness among the people through the process of cultivation (Bildung), while also displaying national identity within inter-ethnic or international relations" (Juvan 2008: 10). A very similar situation (obviously, with some particularities of its own), can be observed in the Finnish literature of the long nineteenth century. 
The New Women from the Margins

$(1878-1926)^{8}$ and the Finnish writer L. Onerva (Hilja Onerva Lehtinen, $1882-1972)^{9}$ precisely through this lens.

\section{Shared Inspiration: Laura Marholm and Ellen Key}

In order to understand the concerns of women writers from the peripheries of Europe, it is useful to locate their work within the context of their more famous contemporaries. In thinking about the New Woman and issues such as emancipation and love, the names Laura Marholm (1854-1928) and Ellen Key (1849-1926) come immediately to mind. Although both can be characterised as Nordic writers (Key was Swedish, Marholm a Baltic German who spent much of her life in Scandinavia), they were read not only in Finland, but also

8 Kveder played an important role in cultural life at the end of the nineteenth century and the beginning of the twentieth century in Slovenia, which was then a part of the AustroHungarian Empire. She had a difficult childhood (both of her parents had abused her physically) in the countryside. When she was only sixteen years old, she fled to the nearest large town where she worked as a secretary. Although she had not attended secondary school, she longed to study. Her dream came true in Bern (Switzerland), where female students could study at the university after a successful interview with the Rector. After a few months she dropped out of university, because she could not study and earn enough money to make ends meet. In the year 1900, she made it to Prague. She established contact with feminists from various Central and South-Eastern European countries. In 1901, Kveder gave birth to a daughter, Vladoša. In 1906, she moved with her family from Prague to Zagreb (in Croatia). Her daughters Marija and Mira were born in 1906 and 1911 respectively. In 1915, during World War One, Croatian women chose Kveder as their delegate to the International Women's Congress at The Hague. She died in Zagreb in 1926.

9 A versatile figure in early twentieth century Finnish cultural life, L. Onerva (whose pen name originates from the abbreviation of her surname "Lehtinen" and her second Christian name, Onerva) can be understood in much the same terms as Zofka Kveder. In Finland, L. Onerva introduced ideas from France, as a writer of poetry and prose, essayist, critic, translator and cultural mediator. She had a traumatic relationship with her mother, who abused her and who was confined to a mental asylum when L. Onerva was seven years old. L. Onerva never had children of her own and, in the 1940s, she herself spent about six years in an asylum, where she was kept so long according to the wishes of her second husband. She belonged to the first generation of Finnish women who were allowed to study at the university without a special permit. Her major interests were literature and art history. She traveled extensively, mostly in France, Germany and Italy. By personal example and in her writing, she fought for women's emancipation, but did not have an easy relationship with Finland's women's movement. She published almost all of her work between 1900 and 1950, but continued to write poems untill the end of her life in 1972. 
in Slovenia and throughout Europe. ${ }^{10}$ Key and Marholm were famous for their views on free love, marriage and motherhood, vis à vis the debates about new representations of femininity, or, in our terms, vis à vis the New Woman. It is interesting to compare their views with other European New Woman authors of their time, although we cannot always be certain about when we should speak of influence or confluence in relation to the spread of ideas.

Although Zofka Kveder quoted Marholm's words in her debut collection of short stories, Misterij žene (The Mystery of Woman, 1900), she fell back on quoting Ellen Key in her most provocative representations of the New Woman. She cited the German translation of Key's essay (Die Frau. Weibliche Sittlichkeit; in: Essays, 1899), where the Swedish writer claimed that love is immoral without marriage, and marriage immoral without love. Kveder made her own position explicit by writing that the words of the Swedish writer were the sacred commandment of pure souls. Thus, she also commented on the notion of free love, a topical issue at the time.

L. Onerva did not respond to Marholm or Key as directly as Kveder, or with the same level of admiration. She did mention Key in a newspaper essay, in a rather critical way, pointing out that "Key sees the ideal relationship of the future as one between an old, nurturing and protective woman and a young, receptive man, reflecting his fairy godmother" (L. Onerva 1909a). In an essay about Alfred de Musset's female characters, she proclaimed that women "exist only for love, only for man" (L. Onerva 1905) in what might be regarded as a Marholmian manner. However, in her prose, when dealing with themes such as free love, marital love, and other controversial aspects of women's emancipation, L. Onerva drew into question not only Key's, but also Marholm's views. ${ }^{11}$

\section{The New Woman as an Independent Figure in the Search for Love and Professional Fulfilment}

At the end of the nineteenth century, Slovene women writers, and particularly Zofka Kveder created the figure of the New Woman, defined in terms of her financial independence, education and rejection of the petty-bourgeois double

10 See the database Women Writers: http://neww.huygens.knaw.nl

${ }_{11}$ In Finland, Ellen Key's reception was richer than Marholm's, although Key was received in an ambivalent fashion. The more progressive section of the women's movement received her positively, while the conservative groups criticised her severely. Marholm's reception was similarly equivocal (see e.g. Rajainen 1973: 64-65, 86; Tuohela 2008: esp. 22-23). 
standard. Her characters actively pursue their own happiness, and strive for intellectual and personal growth. When they find a man who accepts them as they are, they are prepared to cast off the prejudices and rituals they were brought up with. In both her journalism and literary texts, Kveder emphasised the problems faced by young girls who were poor and wanted to study. She knew first-hand that the path to higher education was closed to most of them, as their everyday struggle for survival drained them of the energy and strength needed to complete their studies.

By the turn of the century, Kveder personified the New Woman. She lived alone in a metropolis, earned a living from writing, wore her hair short, smoked cigarettes and enjoyed sex outside of marriage, but at the same time, her everyday existence involved a relentless fight for survival. Perhaps this is why the image of the New Woman, as it appeared in popular fin de siècle culture, is depicted so ironically. Her sketch, Ena iz množice (One of Many), concludes with Pavla's death and the words: "Everything about her was calculated and measured for effect, and even in the few hours before her death, she was giving instructions about how many candles should burn and how she should be laid out and dressed to make her look her best. She was, after all, the daughter of our nervous age, which is strained to the extreme and hungry for nothing but sensation" (Kveder 2010: 659). Autobiographical accounts constantly feature in Kveder's writings. Since she lived the life of a modern intellectual who experienced happiness and despair in love, and since she was able to find fulfilment as a mother and an artist, her autobiographical texts are also a psychogram emblematic of the New Woman.

Finnish women writers also had a specific agenda with which to deal. For L. Onerva, the issues of women's education and access to professional life were very important, both in her writing and everyday life. Art and artistic creation, sexuality, motherhood and the double standard were also of great concern to her. As in many other countries, New Woman writers in Finland mostly depicted the lives of women from the middle classes, as L. Onerva did. However, they also depicted the lower middle class or lower classes, and one of the big themes of the turn of late nineteenth and early twentieth century texts is the phenomenon of social climbing. In this context, the New Woman becomes an ambivalent figure in many senses, not only because of being "positive" and "negative" at the same time.

L. Onerva's New Woman was often a kind of a parvenu, a social climber (which, in the literary character of the Finnish nousukas, acquired special 
meaning ${ }^{12}$ ), an in-between, indeterminate human being, longing to belong and suffering for her uprootedness. In her collection of short stories, Nousukkaita (Parvenus, 1911) and in other prose texts, L. Onerva analysed women characters from the urban milieu, frequently aspiring artists, students (including "rural students," young people from the countryside who had come to the city to study), or intellectuals. Quite often, L. Onerva's New Woman expressed an ambivalent attitude towards the "national project", that is, towards the patriotic desires of her contemporaries. And the same goes for faith and religion: L. Onerva was very critical of the church, but spirituality was of great importance to her. The contradictory elements of her protagonists' spiritual, emotional and intellectual lives limit their happiness. In the novel Inari from 1913 the narrator tells us: "[s] he had the nervous system of the woman of the past, and the brains and will of the woman of the future. She was born to be unhappy." (L. Onerva 1913: 26) A similarly telling example can be seen in the character Ilmi from the short story Itsenäinen nainen (Independent Woman, 1909) who, as the title suggests, achieved independence, but could not attain happiness in love.

\section{The New Woman; Sexuality in Conflict With Reason}

The conflict between sexual passion and reason is a perennial theme in art and literature. However, in New Woman fiction, that conflict took on even greater symbolic significance.

Kveder writes in the novella Telegrafistka (The Telegraphist, 1899) about the tremendously significant late nineteenth century discussion about the incompatibility of women's sexuality and intellect (Nietzsche, Lombroso, Weininger). ${ }^{13}$ For numerous writers, this was a provocative theme, since the New Woman, intellectually comparable to men, aroused both enthusiasm and, to an even greater extent, unease. In this novella Kveder explicitly depicts the female protagonist's love ecstasy. The relationship between Liza and her married lover Viljko is passionate, they are equal partners, however, such a relationship is doomed. When Viljko's pregnant wife Milka, who is also Liza's best friend, discovers the lovers in a passionate embrace, she drinks poison

12 Though the word nousukas is often translated as "parvenu", "social climber", "upstart", or even "nouveau riche", the original meaning of the Finnish word was not only negative. In Finland in the nineteenth and early twentieth centuries, social climbing took place not only as people got richer, but an important way to ascend the social hierarchy was through education, which was also often intertwined with patriotic ideals.

13 See Battersby (1989: 122). 
in the heat of the moment. She is saved from death, but Liza knows that her relationship with Viljko is over, hence she commits suicide by drowning at sea.

The reason Kveder's New Woman does not find happiness in love is directly related to her fear of violating the rules of the middle-class social world to which she belonged. The middle-class double standard punished women who transgressed the boundaries of acceptability by engaging in the pleasures of sexual love outside of marriage. The fear of being labelled immoral and promiscuous was so strong that Kveder's New Woman frequently withdrew from her quest for happiness, rather than openly rebel against societal hypocrisy.

In L. Onerva's prose, the obstacles women had to face in their quest for amorous and sexual fulfilment were multiple. We find characters like Ertta in the Nietzschean short story Lankeemus (Fall, 1909), who experiences sexual attraction all the way to the wild depths of her soul, where, as she believes, dangerous, but fascinating passions are to be found. This is her "true nature". The irony of this story is that Ertta is encouraged by her rational husband to be "free and equal", but she claims that her nature (of which she is afraid, but over which she claims to exert little control), forces her to do otherwise. In a Marholmian vein, she argues that woman should not be equal or similar to man: "I have not been created to be man's comrade, but his lover, not like him in anything, not competing with him, not to be measured in the same way, but to be as much his ruler as his slave!” (L. Onerva 1909b: 175-176).

Just as Ertta ends up in a state of deep despair or madness, a similar fate befalls L. Onerva's heroines when they cannot reconcile (sexual) passion and reason. Passion is all too consuming for woman. For man, love and sexual desire belong among many aspects of life, while for woman, love is her goal, her entire life, as the character Inari claims, echoing, once again, Marholm's ideas (L. Onerva 1913: 16). When a woman tries to play the part of a Don Juan, her downfall is inevitable if we look to the protagonists of the novel Mirdja (1908), and the short story Raina (1911). Raina shoots herself, probably because she is convinced that men cannot commit to a relationship because she is "too equal in love, sex and conversation". Hence, even those characters who dare to rebel openly against bourgeois conventions and double standards, end up in a state of frustration and despair. Woman's inner inhibitions and contradictions seem even more binding than restrictions that originate in the wider social context. 
PONIŽ, PARENTE-ČAPKOVÁ

\section{The New Woman and the Thin Line Separating Sexual Freedom and Promiscuity}

In the nineteenth century social imagination, a woman's body was either concealed in a respectable bourgeois dress or, in the case of prostitutes, put on display. Their place in literature and the art of the period was symbolic; different bodies called for different interpretations. On the one hand the tyranny of female commodification was critiqued, and on the other, prostitutes signified the dark abyss, evil, impurity, disease and fall (Felski 1995: 19). Given that at the start of the twentieth century a writer was frequently identified as being one with her characters, the prostitute was a perilous metaphor for a woman writer of the middle class (Parente-Čapková 2003: 61).

The prostitute was of interest mostly as a metropolitan character, as a representation of anonymity, of woman swallowed whole by the metropolis. In Misterij žene, Kveder raises this theme in the short story $V$ tržaškem predmestju (In the Trieste Suburb, 1900), in which she depicts prostitutes not as they were widely regarded within bourgeois society, as primitive creatures without emotions, but rather as women who could not endure life without love.

Many of Kveder's texts show the relationship between female characters, bodies and questions of identity, influenced by romantic or sexual relationships. In some texts, Kveder presents the female body through the eyes of men to problematise the uncritical view of women as objects of the male gaze. In the short story Biciklistinja (The Cyclist, 1898), naive Dr Doberšek is enamoured of a graceful cyclist and is curious about who the strange girl is. It is clear to his friend (and the reader) that she cannot be a distinguished lady since she would not be cycling unaccompanied to meet an officer. The image of a young, active, sexually attractive and high-spirited (single) woman cyclist appears in many popular texts depicting the New Woman (Willis 2001: 53), just as it does in Kveder's short story.

In L. Onerva's writing, the figure of the prostitute is central, although we do not find many depictions of "literal" sex workers. For this we need to look to the works of Finnish realists and naturalists, or the works of the early twentieth century Finnish writers who depicted the lives of the women of the lower classes in the countryside and the city. ${ }^{14}$ However, like Kveder, L. Onerva depicts the difficulties experienced by the women of the lower classes, for whom prostitution was often the only way to survive.

14 Such depictions can be found in the works of Ina Lange, Maila Talvio, Elviira Willman and Hilda Tihlä (see Hyttinen \& Melkas 2009). Male authors (e.g. Eino Leino) did indeed tackle the subject. 
Most often in L. Onerva's work, the prostitute appears as a figure of symbolic importance, as a signifier. This enables L. Onerva to critique the way male authors used the prostitute as a catch-all metaphor for so many things (all the ills of society, commodification, hypocrisy and feelings of alienation - see Bernheimer 1989; Felski 1995). L. Onerva also exposes and parodies clichés, such as the "prostitute with a golden heart", or the "prostitute redeemed through love”. L. Onerva's most complex depiction of the prostitute is located in the novel Mirdja, where the protagonist stylises herself into a prostitute-like figure. As Diana Fuss (1995: 74) has shown, the (lower) class prostitute, or the fallen, independent woman, could offer a kind of a liberatory, rebellious alternative for middle class girls and young women to identify with. However, Mirdja's tragic fate shows how female protagonists' and, indeed, the authors' engagement and identification with the figure of the prostitute, is often written from the point of view of the male protagonist (or male writer).

\section{The New Woman in Search of the "New Man"}

Both L. Onerva's and Kveder's protagonists search for heterosexual love, however there are suggestions throughout their texts that love and passion need not be limited to what we refer to today as "heterosexual orientation". In L. Onerva's Mirdja, we find hints of woman's feelings for other women, though the most daring suggestions were eliminated from the final version of the novel (cf. Parente-Čapková 2014, 88). The absence of the "New Man", a partner worthy of the New Woman, remained a major problem for many New Woman authors, and this sense of absence exists in both Kveder's and L. Onerva's texts. As Bernadine, the protagonist of Beatrice Harraden's (1864-1936) novel, Ships That Pass in the Night (1893) shows, the first generation of New Women had to conceal their femininity in order to win rights. In contrast, by the last decade of the nineteenth century, the new generation of New Women wanted more. It was no longer enough for independent women to work so hard to survive that they risked burn-out. They also needed happiness in love.

Kveder depicts intelligent, independent, and attractive women who were frequently unable to sustain relationships with men because they had come to expect so much of them. A recurring obstacle to harmonious relationships is the husband's past, which is only disclosed to the young wife after marriage. While the first generation persisted in bad marriages, suffering in silence, the New Woman walked away. For example, in Kveder's one-act play, Strti (Crushed, 1901), the teacher, Ana, leaves the conductor, Ivan, after losing their child to his syphilis infection. 
Kveder describes the alternative life trajectories available to young female intellectuals in her novella Študentke (The Students, 1900). The protagonists study in Switzerland ${ }^{15}$ and the theme is their search for love. A young Russian, Saša Timofejevna shoots herself when she realises that the father of the child she is carrying does not love her, and that everybody, including her man, sees her as a loose woman for having had love affairs. Her Bulgarian friend, Ana Bogdunova, finds a good-natured husband and she does not takelife too seriously and does not expect too much from it. The Russian, Liza Aleksandrovna, is not completely happy either, in spite of her successful conquest of the man she fell in love with. Expecting a lot from life, the protagonists experience pain. Liza realises: "Oh, one must have something beyond one's personal happiness; perhaps then one may be content." (Kveder 2010: 502-502).

Although these sentiments were revolutionary at the turn of the century, Kveder showed, in her sketch Pogovor (A Conversation, 1907), which centres on a dialogue between the painter Jelka and her friend Ana, that neither a happy family life, nor an understanding husband with whom she can discuss art, nor professional success, provide any guarantee of a happy life. Jelka is a demanding woman with great expectations. As a result, she is often disappointed and in a bad mood, though also aware that she gets a lot from life. The writer concludes that "life is not a bed of roses, no one is flawless, there is no light without shadow, and this is how it should be, or one would choke on all the honey". (Kveder 2013: 346)

The importance of sharing a life with a partner capable of showing respect and making the New Woman his equal, is also foregrounded in Kveder's lengthy novella, Nekaj navadnega (Something Usual, 1910). The protagonist, a forty-year-old teacher named Olga, is a stylishly dressed, assertive woman with a modern hairstyle, a role model to her students. When she visits her friend Mira, she lights a cigarette, symbolising her modern ways. Olga marries a painter who is younger by four years, a professor at the academy in Warsaw. Kolienski is an idealist and a dreamer, while Olga, a realist, drives their marriage to ensure its success, especially after they have a child. As a mature woman she expects little from her husband. In her conversation with Mira, she claims that she would not take infidelity too seriously. Mira is different from her friend, and is upset by her husband's cheating ways. She is also hurt by his bluntness when he tells her they will not be having any children, because they could be

15 In the nineteeth century, Switzerland was a popular study destination for foreign female students because women could enroll in most universities without having completed the matriculation examination (Matura, Abitur), the entrance requirement for almost all universities in the Austro-Hungarian Empire and Germany. 
damaged by his promiscuity. By the end of the novella, Mira is a middle-class wife, resigned to her lot, who whiles away her days performing acts of charity, while Olga lives a harmonious life with the man she loves. The novella Nekaj navadnega foregrounds the new, modern woman who, despite being different, finds happiness once she abandons her middle-class prejudices.

In L. Onerva's texts, the difficulty faced by the New Woman in finding her "New Man" is emphasised repeatedly, as we saw in the previous discussion about Ilmi from Itsenäinen nainen, or Raina. In the short story Marketta Salminen (1909), a tenacious entrepreneur is disappointed in love. Her life was ruined by a lazy decadent dandy, with whom she has a daughter. She makes a huge effort to warn her daughter against repeating her mistake, and forbids her to daydream or to indulge in romance. The young Meiri (Meiri, 1909) for her part, suffers in her marriage to a patronising, much older man. The husband treats her like a child, very much in keeping with the nineteenth century "scientific" theories that likened women to children and other "primitive" human beings (cf. e. g. Dijkstra 1986).

Men's most serious limitation seemed to be their attachment to outmoded stereotypes in relation to gender roles. Such was the case with Dr. Orismala in L. Onerva's short story Hävittävää voimaa (Destroying Power, 1912). The married man, Orismala, enchanted by his colleague Sinikka, celebrates the ideal of free love, but Sinikka accuses him of hypocrisy. Seen from her perspective, Orismala's ideas “suspiciously” resemble the old double standard. He exploits sexual availability without offering any commitment in return.

Positive depictions of men can be found in characters who do not appear completely "real", like Runar, the late husband of the protagonist of the novel Mirdja. Mirdja is able to love her partner only in old age and madness. She comes to love him completely only after his death. It is significant that the only version of Runar that she can love, has already lost his "male" characteristics. In companionate old age, they both call themselves "big children" and the issue of sexual difference ceases to exist (cf. Parente-Čapková 2014: 164-170). The man who comes closest to the ideal of the New Man, the partner worthy of the New Woman, is the boyish or even feminine young artist Alvia ${ }^{16}$ in Inari. Alvia adores Inari sincerely and devotedly, but does not resemble the effeminate (and often misogynist) decadent dandies. However, Inari's inability to choose between Alvia and her older lover Porkka still prevents her from being fully happy. For L. Onerva's New Woman, there seems to be a clear benefit in

${ }_{16}$ Inari is partly autobiographical. Alvia was modelled on L. Onerva's second husband, the distinguished Finnish composer Leevi Madetoja, who was five years younger than L. Onerva. [Cf. Kveder's novella Nekaj navadnega.] 
PONIŽ, PARENTE-ČAPKOVÁ

engaging in amorous relationships with only certain kinds of men - men with as few "masculine" characteristics as possible, "feminine" men who are capable of being nurturing, patient and devoted. This ideal, almost unobtainable, lies just outside of the models of love available in the discourses of the day, even the texts of Key and Marholm.

\title{
6. Conclusion
}

L. Onerva and Kveder, both living in countries imagined as being at the periphery of the nineteenth century European literary map, depicted the New Woman in a particular way. Speaking from the margins, they shared the experience of being woman writers who sought out ways of addressing the problems of female identity in societies obsessed with cultural nationalism and that saw woman primarily in terms of her role as wife and mother. L. Onerva and Kveder, manifesting many elements of confluence, depicted a kind of New Woman who wanted to live her life on her own terms, but who was also painfully aware of the difficulty of such an enterprise. Both writers came to understand that woman's internal ambivalences and inhibitions often exerted stronger influence over her than external forces ever could. L. Onerva and Kveder enriched Finnish and Slovenian literature with bold new themes and characters, contributing their own spin on provocative ideas about love, sexuality, and emancipation. In this sense, they also contributed to the perennial task of all fiction: engagement in a process of mimesis, that is, in formulating, by means of creative enterprise, both a reflection of, and challenge to the status quo. Their radical re-interpretation would re-emerge in other discourses only later.

\author{
Katja Mihurko Poniž \\ katja.mihurko.poniz@ung.si \\ University of Nova Gorica \\ School of Humanities \\ Research Centre of Humanities \\ Vipavska 13 \\ SI 5000 Nova Gorica \\ SLOVENIJA
}


The New Women from the Margins

\author{
Viola Parente-Čapková \\ viocap@utu.fi \\ Historian, kulttuurin ja taiteiden tutkimuksen laitos \\ Turun Yliopisto \\ 20014 Turku \\ SUOMI
}

\title{
References
}

Bernheimer, C. 1989. Figures of Ill Repute: Representing Prostitution in NineteenthCentury France. Cambridge, Massachussetts \& London, England: Harvard University Press.

Cohen M. / Dever, C. 2002. The Literary Channel: The Inter-National Invention of the Novel. Princeton: Princeton University Press.

Dijkstra, B. 1986. Idols of Perversity. Fantasies of Feminine Evil in Fin de Siècle Culture. New York and Oxford: Oxford University Press.

Dowling, L. 1979. The Decadent and the New Woman in the1890s. - NineteenthCentury Fiction, 33, 4, 434-453.

Felski, R.1995. The Gender of Modernity. Cambridge (Mass.) \& London: Harvard University Press.

Fuss, D. 1995. Identification Papers. London \& New York: Routledge.

Higgonet, M. 1986. Speaking Silences: Women's Suicide. - S. Rubin Suleiman, ed., The Female Body in Western Culture. Contemporary Perspectives. Cambridge, Massachusetts \& London, England: Harvard University Press, 68-83.

Hyttinen, E., Melkas, K. 2009. 'Me olemme teidän luomianne olentoja.' Prostituoidun hahmo kirjallisena kiistakuvana vuonna 1907. - K. Launis, M. Tikka, eds., Tyoväki ja kokemus. Helsinki: Työväen historian ja perinteen tutkimuksen seura, 122-137.

Jensterle-Doležal, A. 2008. Podobe identitete in travma telesa v prozi Zofke Kveder. J. Jahič Honzak, A. Jensterle, eds., Zofka Kveder (1878-1926). Recepce její tvorby v 20. století. Praha: Slovanská knihovna, Národní knihovna.

Kveder, Z. 2005. Zbrano delo 1. Ljubljana: Litera.

Kveder, Z. 2010. Zbrano delo 2. Ljubljana: Založba ZRC.

L. Onerva. 1905. Musset'n naisluonteet. Laudaturtyö. KIA/Literary Archive of the Finnish Literature Society.

L. Onerva. 1908/1956. Mirdja. 3rd ed. - Valitut teokset, Helsinki: Otava.

L. Onerva. 1909a. Eräitä kehitysviivoja. - Helsingin Sanomat 06.01.

L. Onerva. 1909b. Murtoviivoja. Helsinki: Otava.

L. Onerva. 1911. Nousukkaita. Helsinki: Yrjö Weilin \& kumpp.

L. Onerva. 1912. Mies ja nainen. Helsinki: Kirja.

L. Onerva. 1913. Inari. Helsinki: Weilin \& Göös.

L. Onerva. 1915. Vangittuja sieluja. Helsinki: Kirja. 
PONIŽ, PARENTE-ČAPKOVÁ

Launis, K. 2005. Kerrotut naiset. Suomen ensimmäiset naisten kirjoittamat romaanit naiseuden määrittälijöinä. Helsinki: Suomalaisen Kirjallisuuden Seura.

Ledger, S. 1997. The New Woman: Fiction and Feminism at the Fin de Siècle. Manchester; New York: Manchester University Press.

Leerssen, J. 2006. National Thought in Europe: A Cultural History. Amsterdam: Amsterdam University Press.

MacKay, C. H. 1994. Lines of Confluence in Fredrika Bremer and Charlotte Brontë. - NORA, 2, 119-129.

Mihurko Poniž, K. 2003. Drzno drugačna. Zofka Kveder in podobe ženskosti. Ljubljana: Delta.

Mitchell, S. 1999. New Women, Old and New. - Victorian Literature and Culture 27, 2, 579-588.

Moretti, F. 1998. Atlas of the European Novel, 1800-1900. London, New York: Verso.

Parente-Čapková, V. 2003. Free Love, Mystical Union or Prostitution? The Dissonant Love Stories of L. Onerva.- P. Lyytikäinen ed., Changing Scenes. Encounters between European and Finnish Fin de Siècle. Studia Fennica Litteraria,1. Helsinki: Finnish Literature Society, 54-84.

Parente-Čapková, V. 2014. Decadent New Woman (Un)Bound: Mimetic Strategies in L. Onerva's Mirdja. Turku: Annales Universitatis Turkuensis, Humaniora, Ser. B, Vol. 378.

Rajainen, M. 1973. Naisliike ja sukupuolimoraali. keskustelua ja toimintaa 1800luvulla ja nykyisen vuosisadan alkupuolella noin vuoteen 1918 saakka. Suomen Kirkkohistoriallisen Seuran toimituksia 91. Helsinki: Suomen Kirkkohistoriallinen Seura.

Showalter, E. 1993. Daughters of Decadence: Women Writers of the Fin-de-Siècle. New Brunswick (N. J.): Rutgers University Press.

Tuohela, K. 2008. Huhtikuun tekstit. Kolmen naisen koettu ja kirjoitettu melankolia 1870-1900. Helsinki: Suomen Kirjallisuuden Seura.

Willis, C. 2001: “Heaven Defend Me from Political or Highly Educated Women!”: Packaging the New Woman for Mass Consumption. A. Richardson, C. Willis, eds., The New Woman in Fiction and in Fact: Fin-de-Siècle Feminisms. Basingstoke; New York: Palgrave Macmillan, 53-65.

Witt-Brattström, E. ed., 2004. The New Woman and the Aesthetic Opening: Unlocking Gender in Twentieth-Century Texts. Södertörn Academic Studies 20. Stockholm: Södertörn högskola. 